\title{
Bond of Top-Cast Bars in Bridge Decks
}

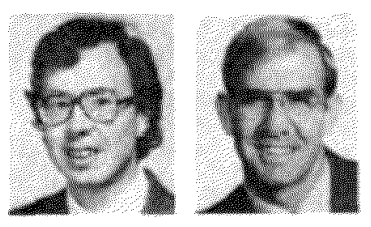

\author{
by Rex C. Donahey and David Darwin
}

The effects of consolidation method and two-course construction on the bond strength of top-cast reinforcement in concrete bridge decks were studied as functions of slump, bleed, and slab depth. Consolidation was varied using vibrator spacing and insertion time. Four top covers were studied: $3 / 4$ and $3 \mathrm{in}$. (19 and $76 \mathrm{~mm}$ ) monolithic and 3 in. (76 mm) two-course with either $3 / 4$ or 1 in. (19 or $25 \mathrm{~mm}$ ) first course cover. Bond test specimens were of two types: shallow, with 8 in. $(203 \mathrm{~mm})$ of concrete below the reinforcement, and deep, with 24 in. $(610 \mathrm{~mm})$ of concrete below the reinforcement. Concrete densities were obtained from drilled cores.

Based on the experimental work, high-density internal vibration provides improved bond over low-density internal vibration. $A 3 \mathrm{in}$. (76 $\mathrm{mm}$ ) monolithic cover provides higher bond strength than 3 in. (76 $\mathrm{mm}$ ) two-course cover. Increased concrete slump has a negative effect on bond strength for top-cast reinforcement. Deep slabs made with stiff, well-consolidated concrete can provide the same bond strengths as shallow slabs.

Keywords: air entrainment; bond (concrete to reinforcement); bleeding (concrete); bridge decks; concrete construction; consistency; consolidation; cover pullout tests; reinforced concrete; reinforcing steels; resurfacing; vibration.

Attempts to solve the problem of corrosion of reinforcing steel in bridge decks have led to the introduction of innovative procedures for new deck construction. Two of these procedures, two-course bonded deck construction and high-density internal vibration are relatively untested for their effects on concrete-steel bond strength.

Two-course bonded deck construction places a highquality concrete wearing surface on a previously placed and cured first course. It has been found, however, that due to the low cover initially used over the top steel, a number of problems arise with the first course; the finishing equipment tends to work the coarse aggregate away from the reinforcing bars, while settlement cracks form in the first course over the reinforcing bars. These factors, may, in turn, affect the concrete-steel bond strength.

Bridge deck concrete in Kansas is currently consolidated using high-density internal vibration, with a maximum vibrator spacing of $1 \mathrm{ft}(0.3 \mathrm{~m})$. This method is intended to be an improvement over consolidation using hand-held vibrators. Although it is generally accepted that good consolidation leads to good concrete, it is not clear what effect high-density vibration has on concrete-steel bond.

This paper presents the results of a study of the effects of consolidation method and two-course construction on the bond strength of top-cast bars in bridge decks as a function of concrete slump and bleed, and slab depth. The results are analyzed and compared with predictions of the AASHTO Bridge Specifications ${ }^{1}$ and the ACI Building Code. ${ }^{2}$ Recommendations are made. Additional details of this study are presented in References 3 and 4 .

\section{Significance of the research}

This research has specific significance in bridge deck design and construction. It points out that high-density internal vibration can improve concrete-steel bond strength as well as concrete quality, and illustrates a number of potential problems with the widely used twocourse bridge deck construction method. Of broader significance, the research emphasizes the negative effects of thin cover and high-slump concrete on bond strength.

\section{EXPERIMENTAL WORK}

To study the effects of consolidation method and top cover on bond in bridge decks, test specimens, placement procedures, and test procedures were selected to reflect actual deck thicknesses, placement procedures, and loading.

\section{Test specimens}

The study used eighteen $4 \times 8 \mathrm{ft}(1.2 \times 2.4 \mathrm{~m})$ shallow deck specimens, with 8 in. $(203 \mathrm{~mm})$ of concrete below the top reinforcement (Fig. 1), and five $3 \times 4 \mathrm{ft}(0.9 \times$ $1.2 \mathrm{~m}$ ) deep deck specimens, with $24 \mathrm{in}$. of concrete below the top reinforcement (Fig. 2). Four top covers were studied, $3 / 4$ and $3 \mathrm{in.}(19$ and $76 \mathrm{~mm}$ ) monolithic top covers and 3 in. (76 mm) two-course top covers with either $3 / 4$ or $1 \mathrm{in}$. (19 or $25 \mathrm{~mm}$ ) first course cover. The reinforcement was \#5 $(16 \mathrm{~mm})$ and $\# 8(25 \mathrm{~mm})$ deformed bars. A total of 117 bars were tested.

Received Aug. 17, 1983 and reviewed under Institute publication policies. Copyright (C) 1985. American Concrete Institute. All rights reserved, including the making of copies unless permission is obtained from the copyright proprietors. Pertinent discussion will be published in the November-December 1985 ACI JOURNAL if received by Aug. 1, 1985. 
ACI Member Rex C. Donahey received his BSCE from the University of Kansas, Lawrence. He was a project engineer for the Marley Cooling Tower Co. for 3 years. He has since received his MSCE and is currently pursuing a PhD at the University of Kansas.

David Darwin, FACI, is a professor of civil engineering and director of the Structural Engineering and Materials Laboratories at the University of Kansas, Lawrence. $\mathrm{He}$ is an active researcher in the fields of plain and reinforced concrete, chairman of ACl Committee 224, Cracking, a member of ACI Committee 408, Bond and Development of Reinforcement, and ACI-ASCE Committee 445, Shear and Torsion, and past-president of the Kansas Chapter of $\mathrm{ACl}$.

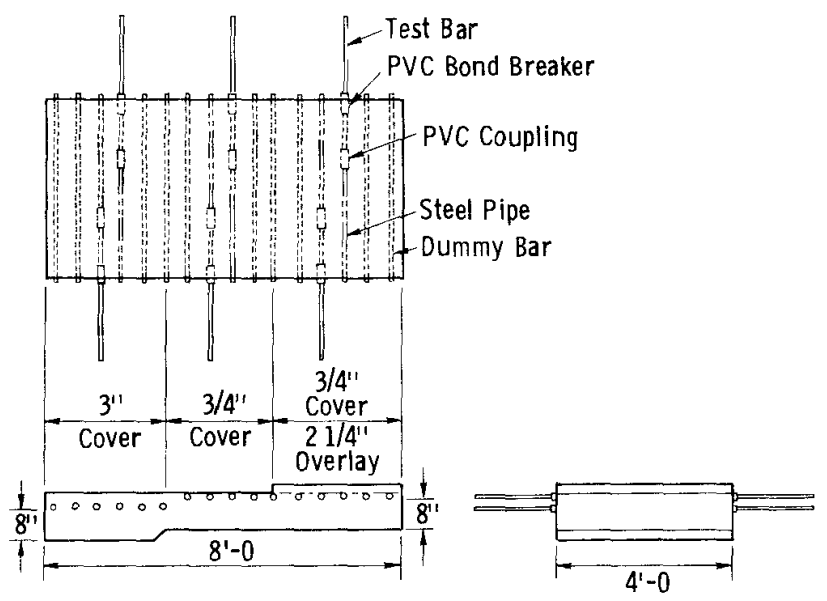

Fig. 1 - Shallow slab $(1 \mathrm{in} .=25.4 \mathrm{~mm})$

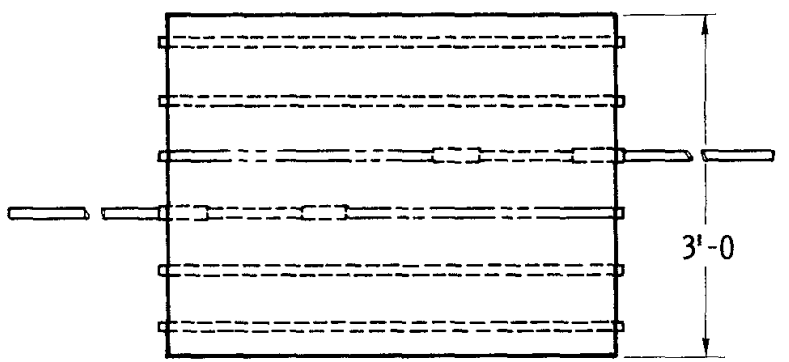

$3 / 4^{\prime \prime}$ or $3^{\prime \prime}$ Cover

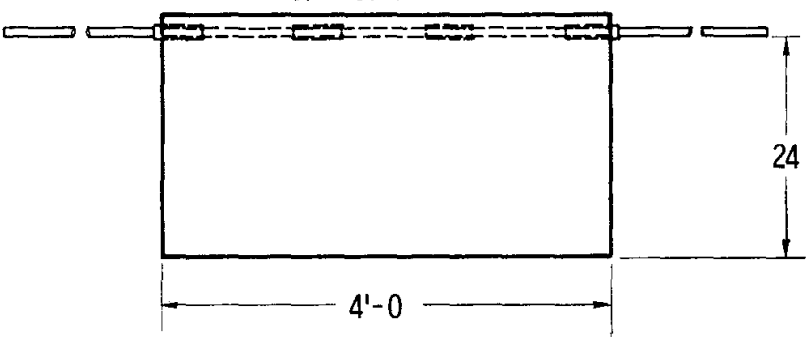

Fig. $2-$ Deep slab $(1 \mathrm{in} .=25.4 \mathrm{~mm})$

The shallow specimens were stepped down $21 / 4$ in. (57 $\mathrm{mm}$ ) in the third of the form containing the 3 in. (76 $\mathrm{mm}$ ) monolithic cover to maintain a constant 8 in. (203 $\mathrm{mm}$ ) depth below the reinforcement. Shallow specimens contained six test bars. Ten dummy deformed bars (not tested) were installed in the form to allow aggregate bridging, which tends to restrict settlement.

Deep specimens contained two test bars and four dummy bars.

The test program is summarized in Table 1.
Table 1 - Summary of test program

\begin{tabular}{|c|c|c|c|c|}
\hline Slab & $\begin{array}{l}\text { Bar } \\
\text { size }\end{array}$ & $\begin{array}{c}\text { Consolidation } \\
\text { type* }\end{array}$ & $\begin{array}{c}\text { Embedment } \\
\text { length, in. }\end{array}$ & Cover, in. (number of bars) \\
\hline la & $\# 8$ & $\mathrm{H} 2$ & 12 & $3 / 4(4), 3(2)$ \\
\hline $1 b$ & $\# 8$ & $\mathrm{H} 1$ & 12 & $3 / 4(4), 3(2)$ \\
\hline $1 \mathrm{c}$ & $\# 8$ & $\mathrm{H} 2$ & 12 & $3 / 4(3), 3(2)$ \\
\hline $2 a$ & $\# 8$ & $\mathrm{H} 2$ & 10 & $3 / 4(4), 3(2)$ \\
\hline $2 b$ & $\# 8$ & $\mathrm{H} 2$ & 10 & $3 / 4(2), 3 / 4+21 / 4(2), 3(2)$ \\
\hline $2 c$ & $\# 8$ & L1 & 10 & $3 / 4(2), 3 / 4+21 / 4(2), 3(2)$ \\
\hline $3 a$ & $\# 8$ & $\mathrm{H} 2$ & 10 & $3 / 4(2), 3 / 4+2^{1 / 4}(2), 3(2)$ \\
\hline $3 b$ & $\# 8$ & $\mathrm{H} 2$ & 10 & $3 / 4(4), 3(2)$ \\
\hline $3 \mathrm{c}$ & $\# 8$ & Ll & 10 & $3 / 4(2), 3 / 4+2^{1 / 4}(2), 3(2)$ \\
\hline $4 a$ & \#5 & L1 & 5 & $3 / 4(4), 3(2)$ \\
\hline $4 b$ & \#5 & $\mathrm{H} 2$ & 5 & $3 / 4(4), 3(2)$ \\
\hline $5 a$ & \#5 & L1 & 3.5 & $3 / 4(2), 3 / 4+21 / 4(2), 3(2)$ \\
\hline $5 b$ & $\# 5$ & $\mathrm{H} 2$ & 3.5 & $3 / 4(2), 3 / 4+21 / 4(2), 3(2)$ \\
\hline $6 a$ & $\# 5$ & L2 & $\begin{array}{l}12 \\
3.5\end{array}$ & $\begin{array}{c}3 / 4(2) \\
3 / 4+2^{1 / 4}(2), 3(2)\end{array}$ \\
\hline $6 b$ & $\# 5$ & $\mathrm{H} 2$ & $\begin{array}{l}12 \\
3.5\end{array}$ & $\begin{array}{c}3 / 4(2) \\
3 / 4+21 / 4(2), 3(2)\end{array}$ \\
\hline $7 a$ & $\# 8$ & $\mathrm{H} 2$ & 15 & $3 / 4(2)$ \\
\hline & & & 10 & $3 / 4+21 / 4(2), 3(2)$ \\
\hline $7 b$ & $\# 8$ & L3 & 15 & $3 / 4(2)$ \\
\hline & & & 10 & $3 / 4+21 / 4(2), 3(2)$ \\
\hline $7 \mathfrak{c}$ & $\# 8$ & $H 2$ (D) & 10 & $3(2)$ \\
\hline $7 \mathrm{~d}$ & $\# 8$ & $\mathrm{H} 2(\mathrm{D})$ & 15 & $3 / 4(2)$ \\
\hline $8 \mathrm{a}$ & $\# 8$ & $\mathrm{H} 2$ & 10 & $3 / 4(2), 3 / 4+21 / 4(2), 3(2)$ \\
\hline $8 b$ & $\# 8$ & $\mathrm{H} 2(\mathrm{D})$ & 10 & $3(2)$ \\
\hline $8 \mathrm{c}$ & $\# 8$ & $\mathrm{H} 2$ (D) & 10 & $1+2(2)$ \\
\hline $8 d$ & $\# 8$ & H2(D) & 10 & $3 / 4+21 / 4(2)$ \\
\hline
\end{tabular}

*Consolidation type designations:

$\mathrm{Hl}=$ high-density vibration at 1 -ft centers using one vibrator

$\mathrm{H} 2=$ high-density vibration at 1 -ft centers using two vibrators

$\mathrm{Ll}=1 \mathrm{ow}$-density vibration at 2 -ft centers

$\mathrm{L} 2=$ low-density vibration at the slab centerline at 2 -ft center

$\mathrm{L} 3=$ low density vibration at 2 -ft centers for $7 \mathrm{sec}$

(D) $\Rightarrow$ deep slab

Note: 1 in. $=25.4 \mathrm{~mm}$, bar sizes: $\# 8=25 \mathrm{~mm}$, $\# 5=16 \mathrm{~mm}$

\section{Material properties}

Concrete-Air-entrained concrete was supplied by a local ready mixed concrete plant for the first course. Type I cement and $3 / 4$ in. $(19 \mathrm{~mm})$ nominal maximum size aggregate were used. Concrete slump was varied using both water content and air content.

The overlay concrete was prepared in the laboratory using Type I cement and $3 / 4$ in. (19 mm) maximum size aggregate, obtained by removing all material retained on a $3 / 4-i n .(19-\mathrm{mm})$ sieve from the coarse aggregate used for the first course. A high-range water reducer was used in the overlays for Slab Groups 7 and 8. Mix proportions, aggregate, and concrete properties are summarized in Table 2.

Steel-ASTM A 615, Grade 60 reinforcing bars were used for all tests. Deformation dimensions and bearing areas were recorded ${ }^{3,4}$ and are presented in Appendix A.*

\section{Placement procedure}

Shallow forms were filled in one lift, and deep forms were filled in two lifts (each lift vibrated equally).

Consolidation was obtained using frame mounted, $17 / 8$-in. (48-mm) diameter pneumatic vibrators, rated by the manufacturer at 11,500 cycles per min at $90 \mathrm{psi}$ $(0.64 \mathrm{MPa})$ pressure in air. Vibrator amplitude was 0.04 in. $(1 \mathrm{~mm})$ (peak to peak).

\footnotetext{
* The appendixes are available in xerographic or similar form from ACl headquarters, where they will be kept permanently on file, at a charge equal to cost of reproduction plus handling at time of request.
} 
Table 2(a) - Concrete mix proportions, lb/yd ${ }^{3}$

\begin{tabular}{|c|c|c|c|c|c|c|c|c|c|c|}
\hline \multicolumn{6}{|c|}{$\begin{array}{l}\text { First course } \\
\text { concrete }\end{array}$} & \multicolumn{5}{|c|}{$\begin{array}{l}\text { Second course } \\
\text { concrete }\end{array}$} \\
\hline \multirow{2}{*}{$\begin{array}{c}\text { Slab } \\
\text { group }\end{array}$} & \multirow[b]{2}{*}{$W / C$} & \multirow[b]{2}{*}{ Cement } & \multirow[b]{2}{*}{ Water } & \multicolumn{2}{|c|}{ Aggregate } & \multirow[b]{2}{*}{$W / C$} & \multirow[b]{2}{*}{ Cement } & \multirow[b]{2}{*}{ Water } & \multicolumn{2}{|c|}{ Aggregate } \\
\hline & & & & Fine* & Coarse & & & & Fine* & Coarse $^{\dagger}$ \\
\hline 1 & 0.44 & 591 & 262 & 1470 & 1455 & - & - & - & - & - \\
\hline 2 & 0.44 & 636 & 282 & 1381 & 1455 & 0.44 & 563 & 248 & 1491 & 1491 \\
\hline 3 & 0.44 & 591 & 262 & 1470 & 1455 & 0.44 & 563 & 248 & 1491 & 1491 \\
\hline 4 & 0.44 & 555 & 244 & 1545 & 1455 & - & - & - & - & - \\
\hline 5 & 0.44 & 591 & 262 & 1470 & 1455 & 0.44 & 563 & 248 & 1491 & 1491 \\
\hline 6 & 0.44 & 584 & 257 & 1484 & 1455 & 0.44 & 563 & 248 & 1491 & 1491 \\
\hline 7 & 0.41 & 591 & 243 & 1515 & 1455 & 0.40 & 620 & 248 & 1447 & 1491 \\
\hline 8 & 0.44 & 591 & 262 & 1470 & 1455 & 0.35 & 825 & 289 & 1316 & 1316 \\
\hline
\end{tabular}

Crushed limestone: bulk specific gravity $=2.52$, absorption $=3.5$ percent, maximum size $=3 / 4$ in

*Kansas River sand. bulk specific gravity $=2.62$, Absorption $=0.5$ percent, fineness modulus $=3.0$

Air entraining agent: vinsol resin

Design air content $=6$ percent.

Note: $1 \mathrm{lb} / \mathrm{yd}^{3}=0.5933 \mathrm{~kg} / \mathrm{m}^{3}$

High-density vibration (vibrator radii of influence overlap) was obtained using either one or two vibrators inserted at $1-\mathrm{ft}(0.3-\mathrm{m})$ centers. Low-density vibration (radii of influence do not overlap) was achieved using a single vibrator inserted at 2-ft $(0.6-\mathrm{m})$ centers. With the exception of Slab Group 6, low-density vibration slabs were vibrated $1 \mathrm{ft}(0.3 \mathrm{~m})$ from each side of the forms. The low-density slab in Group 6 was vibrated at the slab center line only.

Vibrators were inserted rapidly, held in place for 10 sec, and withdrawn slowly. The exception was the lowdensity-vibration slab in group 7 , in which the vibrator was held in place for $7 \mathrm{sec}$.

Slabs were hand screeded using a metal-edged screed. Two passes were made, with screed travel perpendicular to the top reinforcement in each pass.

Immediately on completion of screeding, the specimens were floated using a magnesium bull float. Bleed and settlement tests were then started.

Special bleed tests were required, since standard bleed tests ${ }^{5}$ yielded very little water from the air-entrained concrete [Table 2(b)]. The tests were performed on the surface of the slabs and used preweighed $51 / 2$ in. $(140 \mathrm{~mm}$ ) square paper towels (from the same lot). The towels were placed on the surface of the concrete and covered with a glass plate to prevent evaporation. When fully saturated, the towels were replaced and the time was recorded. The tests were not solely a measure of bleed, because the towels drew water from the slab surface.

Slab settlement was obtained by measuring the movement of 2 in. $(51 \mathrm{~mm})$ square balsa wood pads resting on the concrete surface, using linear variable differential transformers (LVDT's).

Bleed and settlement tests continued for a minimum of $2 \mathrm{hr}$ after finishing. Following the tests, the slabs were covered with polyethylene until a strength of 3000 psi (21 MPa) was obtained. The polyethylene was then removed and the forms stripped.

At this point, the portions of the slabs to be overlayed were cleaned using a water blaster [rated at 3000 psi (21 MPa)] until all traces of laitance and carbonation were removed. The surfaces were allowed to dry for $2 \mathrm{hr}$ and a 50 percent sand, 50 percent cement (by
Table 2(b) - Concrete properties

\begin{tabular}{c|c|c|c|c|c|c}
\hline \multirow{2}{*}{$\begin{array}{c}\text { Slab } \\
\text { Group }\end{array}$} & \multicolumn{4}{|c|}{$\begin{array}{c}\text { First course } \\
\text { concrete }\end{array}$} & \multicolumn{2}{c}{$\begin{array}{c}\text { Second course } \\
\text { concrete }\end{array}$} \\
\cline { 2 - 7 } & $\begin{array}{c}\text { Slump, } \\
\text { in. }\end{array}$ & $\begin{array}{c}\text { Air, } \\
\text { percent }\end{array}$ & $\begin{array}{c}\text { Bleed, } \\
\mathrm{ml}\end{array}$ & $\begin{array}{c}f_{c}^{\prime}, \\
\text { psi }\end{array}$ & $\begin{array}{c}\text { Slump, } \\
\text { in. }\end{array}$ & $\begin{array}{c}f_{c}^{\prime} \\
\text { psi }\end{array}$ \\
\hline 1 & $21 / 2$ & $41 / 2$ & 0 & 4510 & - & - \\
2 & $81 / 2$ & 9 & 10.8 & 3820 & $1 / 2$ & 5920 \\
3 & $51 / 2$ & 7 & 13.5 & 3970 & $1 / 2$ & 4380 \\
4 & 3 & 7 & 3.5 & 3570 & - & - \\
5 & $23 / 4$ & 5 & 0 & 4910 & $1 / 4$ & 5670 \\
6 & $41 / 2$ & 10 & 2 & 4060 & 0 & 2600 \\
7 & $13 / 4$ & 5 & 0 & 4950 & 0 & 5100 \\
8 & $21 / 4$ & 7 & 0 & 3970 & $1 / 2$ & 5350 \\
\hline
\end{tabular}

*ASTM C 232, at $100 \mathrm{~min}$

Note: $1 \mathrm{in} .=25.4 \mathrm{~mm} ; 1$ psi $=6.895 \mathrm{kPa}$

weight) grout was applied using a stiff brush. The grout had the consistency of a thick cream.

The overlay concrete was placed on the wet grout and consolidated using a pneumatic vibratory screed. The screed rode on a $2 \frac{1 / 4}{4}$ in. $(57 \mathrm{~mm})$ high form. The overlays were hand floated using a magnesium float and cured under plastic until a strength of 4000 psi ( 28 $\mathrm{MPa}$ ) was attained or until the overlay strength was as high as the first course strength [one exception to this practice was Group 6, where the overlay strength was only $2600 \mathrm{psi}(18 \mathrm{MPa})$ at the time of the pullout tests].

\section{Test procedure}

The pullout apparatus shown in Fig. 3 was used for the bond tests. The equipment was designed so that the test bars would be loaded in tension without placing the surrounding concrete in compression.

Each slab group was tested within $24 \mathrm{hr}$. Compression cylinders were tested at the time of the bond tests to determine the slab and overlay strengths.

The bars were loaded at approximately 3 kips $(13 \mathrm{kN})$ per min. Load, loaded-end slip, and unloaded-end slip were recorded as the tests progressed. Cores, 4-in. (102$\mathrm{mm}$ ) diameter, were taken from Groups 6 and 7. Concrete density and void percentage were determined following ASTM C $642^{6}$ with the following exceptions: dry weights were obtained using air-dried specimens rather than oven-dried specimens; saturated weights after immersion were used in place of saturated weights after boiling. 

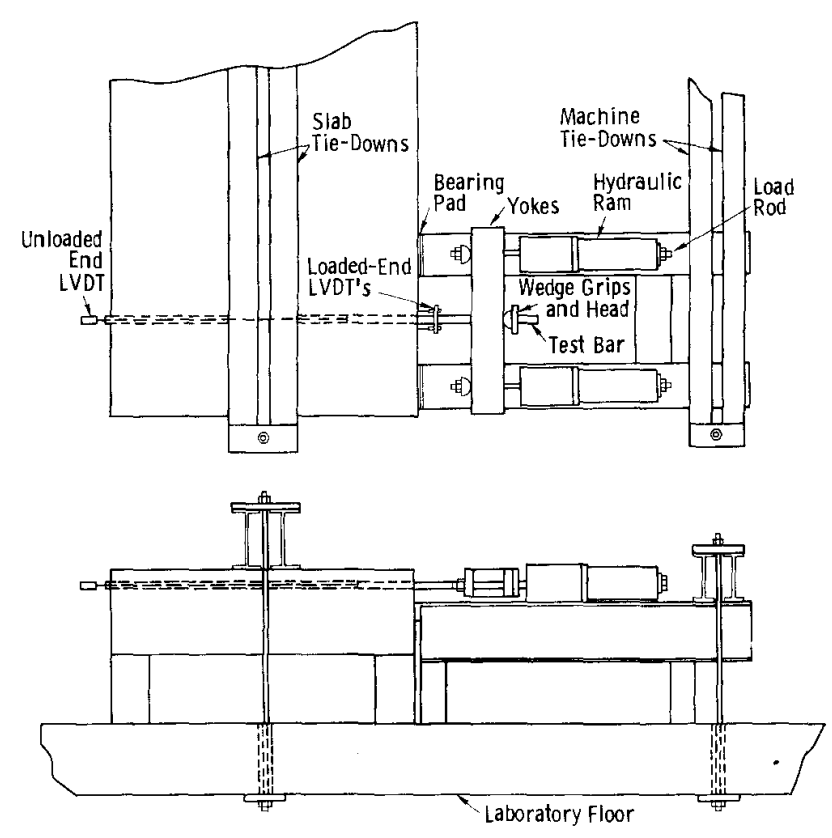

Fig. 3 - Schematic of bond test

\section{Results and observations}

Plastic concrete-Bleeding was initially rapid, but slowed substantially after $90 \mathrm{~min}$. With the exception of Groups 1, 2, and 3, bleed did not vary significantly between individual slabs in a group. The differences in Groups 1,2, and 3 were due to methods of placement, which were corrected in later work. ${ }^{3}$

For the valid comparisons, the maximum difference in bleed occurred in Slab Group 5, with a ratio of bleed obtained with high-density vibration to bleed obtained with low-density vibration of 0.84 . Ratios for Groups 4,6 , and 7 were $0.94,1.01$, and 1.01 , respectively.

The settlements were extremely low for all specimens [maximum of 0.012 in. $(0.30 \mathrm{~mm})$ ], and seemed to indicate that both consolidation densities were satisfactory from the point of view of settlement.

The results from the bleed and settlement tests are presented in Table 3.

Hardened concrete-Settlement cracks were noted above the bars with $3 / 4-$ in. $(19-\mathrm{mm})$ cover in Slab Groups 2, 4, 5, and 6. Group 2 contained $\# 8$ bars and was placed with $81 / 2-i n$. $(216-\mathrm{mm})$ slump concrete. The other three groups contained \#5 bars.

For both bar sizes, the behavior and failure mode in the pullout tests depended on the cover. All failures were splitting failures, except for the \#5 bars with a 3in. (76- $\mathrm{mm}$ ) cover, which rarely displayed any cracking.

Bars with $3 / 4-$ in. (19-mm) cover failed at lower loads than bars with 3 -in. (76-mm) cover, while bars with two-course cover normally failed at loads below the failure loads for $3 \mathrm{in}$. (76 mm) monolithic cover.

The complete test data are available in References 3 and 4 and in Appendix B.*

The cores showed extremely good bond between the overlay and the first course concrete.
Table 3-Slab bleed and settlement at $2 \mathrm{hr}$

\begin{tabular}{|c|c|c|c|}
\hline Slab & $\begin{array}{c}\begin{array}{c}\text { Consolidation } \\
\text { type* }\end{array} \\
\end{array}$ & $\begin{array}{c}\text { Average total } \\
\text { bleed, } \\
\text { gm }\end{array}$ & $\begin{array}{c}\text { Settlement, } \\
\text { in. }\end{array}$ \\
\hline $1 \mathrm{a}$ & $\mathrm{H} 2$ & 14.4 & 0.010 \\
\hline $1 \mathrm{~b}$ & $\mathrm{H} 1$ & 8.8 & 0.008 \\
\hline le & $\mathrm{H} 2$ & 9.5 & 0.006 \\
\hline $2 a$ & $\mathrm{H} 2$ & 57.3 & 0.010 \\
\hline $2 b$ & $\mathrm{H} 2$ & 43.5 & No data \\
\hline $2 c$ & $\mathrm{~L} 1$ & 39.4 & No data \\
\hline $3 a$ & $\mathrm{H} 2$ & 41.3 & 0.004 \\
\hline $3 \mathrm{~b}$ & $\mathrm{H} 2$ & 26.2 & 0.007 \\
\hline $3 \mathrm{c}$ & LI & 28.2 & 0.009 \\
\hline $4 a$ & L1 & 31.0 & 0.010 \\
\hline $4 b$ & $\mathrm{H} 2$ & 29.0 & No data \\
\hline $5 a$ & $\mathrm{Ll}$ & 21.4 & 0.011 \\
\hline $5 b$ & $\mathrm{H} 2$ & 17.9 & 0.009 \\
\hline $6 a$ & $\mathrm{H} 2$ & 26.3 & 0.007 \\
\hline $6 b$ & L2 & 26.0 & 0.003 \\
\hline $7 a$ & $\mathrm{H} 2$ & 17.7 & 0.010 \\
\hline $7 b$ & $\mathrm{~L} 3$ & 17.6 & 0.011 \\
\hline $7 \mathrm{c}$ & $\mathrm{H} 2$ (D) & 18.3 & 0.005 \\
\hline $7 d$ & H2(D) & 16.4 & 0.008 \\
\hline $8 \mathrm{a}$ & $\mathrm{H} 2$ & 11.1 & 0.011 \\
\hline $8 b$ & $\mathrm{H} 2$ (D) & 10.6 & 0.012 \\
\hline $8 c$ & H2(D) & 9.3 & 0.003 \\
\hline $8 \mathrm{~d}$ & $\mathrm{H} 2(\mathrm{D})$ & 11.6 & 0.005 \\
\hline
\end{tabular}

* See Table 1 for notation.

Note: $1 \mathrm{in}$. $=25.4 \mathrm{~mm}$

The cores showed that density increased about 3 percent and void percentage decreased about 4 percent, where high-density consolidation was used. ${ }^{3}$

\section{EVALUATION OF EXPERIMENTAL RESULTS}

Since some bars yielded before reaching the ultimate load, unloaded-end slip was also used for bond force comparison. Unloaded-end slips of 0.010 in. $(0.25 \mathrm{~mm})$ and 0.005 in. $(0.13 \mathrm{~mm})$ were used for $\# 5$ and $\# 8$ bars, respectively.

In Slab Groups 1, 2, and 3, longitudinal splitting cracks crossed the slab centerline for most $\# 8$ bars with 3 -in. (76-mm) cover. In these groups, only the first \#8 bar with 3-in. (76-mm) cover pulled from a slab was used for comparison. Additional transverse reinforcing was added to intercept splitting cracks in Groups 7 and 8 , which allowed both 3 -in. (76-mm) cover bars to be used.

To further assist in the comparisons, the bond forces were converted to bond force per unit length and normalized to a strength of $4000 \mathrm{psi}(28 \mathrm{MPa})$ and to embedment lengths of $10 \mathrm{in}$. (254 mm) and $3 \frac{112}{2}$ in. (89 $\mathrm{mm}$ ) for \#8 and \#5 bars, respectively.

The strength was normalized using the assumption that bond strength is proportional to concrete tensile strength,,$^{7-9}$ which in turn is proportional to the square root of compressive strength. Bond values were, therefore, multiplied by $\left(4000 / f_{c}^{\prime}\right)^{1 / 2}$, where $f_{c}^{\prime}=$ concrete compressive strength (psi).

The embedment length was modified using a nonlinear relation between bond strength and embedment length, developed by Jimenez et al. ${ }^{10}$ The bond forces were divided by an equivalent embedment length, $L_{e}$, obtained from the following expression:

*The appendixes are available in xerographic or similar form from ACI cost of reproduction plus handling at time of request. 


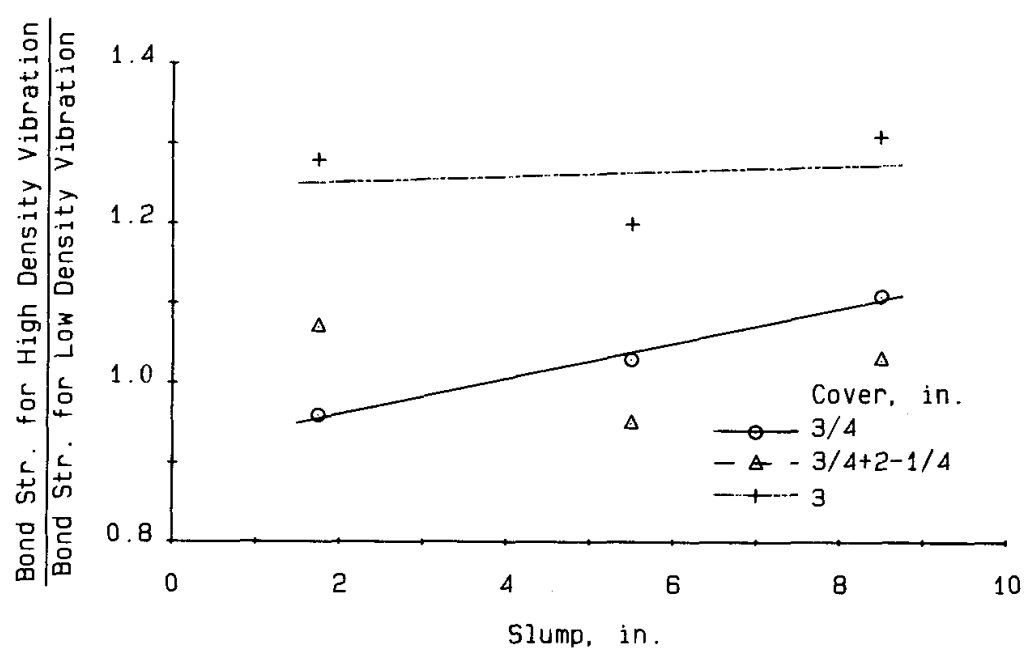

Fig. 4 - Ratio of bond forces for high-and low-density vibration at 0.005-in. slip versus slump (l in. $=25.4 \mathrm{~mm})$

$$
L_{e}=\frac{L\left(35.4 d_{b}+0.573 L_{n}\right)}{\left(35.4 d_{b}+0.573 L\right)}
$$

in which $L=$ actual embedment length, $d_{b}=$ bar diameter, and $L_{n}=$ embedment to which results are normalized.

\section{Effect of consolidation method}

The results indicate that high-density vibration generally improves bond strength, and the amount of improvement is a function of concrete slump. In addition, improved consolidation provides higher unit weights and lower void contents.

The ratios of average bond forces obtained with high-density vibration are compared to bond forces obtained with low-density vibration in Table 4 and Fig. 4. At ultimate, the average ratios for $\# 5$ bars are 1.06 , 1.23 , and 1.05 for $3 / 4 \mathrm{in}$. $(19 \mathrm{~mm}), 3 \mathrm{in}$. $(76 \mathrm{~mm})$ twocourse, and 3 in. ( $76 \mathrm{~mm}$ ) monolithic covers, respectively. The corresponding values for $\# 8$ bars are 1.03 , 1.00 , and 1.04 .

Fig. 4 [bond forces at 0.005 -in. $(013-\mathrm{mm})$ slip] shows that the relative effectiveness of high-density vibration increases with increasing slump for \#8 bars with monolithic cover. The ratios increased from 0.96 to 1.11 for bars with $3 / 4-$ in. (19-mm) cover as the slump increased from $13 / 4$ in. $(44 \mathrm{~mm})$ to $8 \frac{1}{2}$ in. $(216 \mathrm{~mm})$; ratios for bars with 3 in. (76 mm) monolithic cover increased from 1.28 to 1.32 .

The fact that high-density vibration provides a greater relative improvement in bond for higher slump concrete is of interest, since higher slump concrete should need less, not more, consolidation. This suggests that improved consolidation may overcome some of the extra settlement that occurs with high slump. Since low-slump concrete settles less, the extra consolidation may be relatively less effective.

Fig. 4 also shows that high-density vibration provides a much greater benefit for the $\# 8$ bars with the monolithic 3-in. (76- $\mathrm{mm}$ ) cover than for the \#8 bars with either the monolithic $3 / 4-\mathrm{in}$. (19-mm) cover or the two-course 3-in. (76-mm) cover.
Table 4-Ratio of bond strengths for high-density
vibration to bond strengths for low-density
vibration

\begin{tabular}{|c|c|c|c|c|c|c|c|c|}
\hline \multirow{3}{*}{$\begin{array}{l}\mathrm{Bar} \\
\text { size }\end{array}$} & \multirow{3}{*}{$\begin{array}{c}\text { Group } \\
\text { No. }\end{array}$} & \multirow{3}{*}{$\begin{array}{l}\text { Slump, } \\
\text { in. }\end{array}$} & \multirow{2}{*}{\multicolumn{3}{|c|}{$\frac{\text { End-slip value* }}{\text { Cover type }}$}} & \multirow{2}{*}{\multicolumn{3}{|c|}{$\begin{array}{c}\text { Ultimate force } \\
\text { value }\end{array}$}} \\
\hline & & & & & & & & \\
\hline & & & 1 & 2 & 3 & 1 & 2 & 3 \\
\hline$\# 5$ & $\begin{array}{l}4 \\
5 \\
6\end{array}$ & $\begin{array}{l}3 \\
23 / 4 \\
41 / 2\end{array}$ & $\begin{array}{l}0.83 \\
1.35 \\
1.06\end{array}$ & $\begin{array}{l}1.16 \\
1.19\end{array}$ & $\begin{array}{l}0.54 \\
1.23 \\
1.32\end{array}$ & $\begin{array}{l}0.88 \\
1.22 \\
1.07\end{array}$ & $\begin{array}{l}1.23 \\
1.23\end{array}$ & $\begin{array}{l}0.78 \\
1.11 \\
1.25\end{array}$ \\
\hline \multicolumn{3}{|c|}{ Average } & 1.08 & 1.18 & 1.03 & 1.06 & 1.23 & 1.05 \\
\hline$\# 8$ & $\begin{array}{l}2 \\
3 \\
7 \\
\end{array}$ & $\begin{array}{l}81 / 2 \\
51 / 2 \\
13 / 4 \\
\end{array}$ & $\begin{array}{l}1.11 \\
1.03 \\
0.96\end{array}$ & $\begin{array}{l}1.03 \\
0.95 \\
1.08\end{array}$ & $\begin{array}{l}1.32 \\
1.20 \\
1.28\end{array}$ & $\begin{array}{l}1.05 \\
1.05 \\
0.99\end{array}$ & $\begin{array}{l}1.02 \\
0.98 \\
1.00\end{array}$ & $\begin{array}{l}1.08 \\
0.98 \\
1.05\end{array}$ \\
\hline \multicolumn{3}{|c|}{ Average } & 1.04 & 1.02 & 1.27 & 1.03 & 1.00 & 1.04 \\
\hline
\end{tabular}

*End slip $=0.005$ in. for $\# 8$ bars and 0.010 for $\# 5$ bars

${ }^{+}$Cover type designations:

$I=3 / 4$ in. monolithic cover

$2=3$ in. two-course cover

$3=3$ in. monolithic cover

Note: $1 \mathrm{in.}=25.4 \mathrm{~mm}$

This difference may be explained by the formation of settlement cracks in the thin top cover which may dominate the behavior of bars with a $3 / 4$ in. $(19 \mathrm{~mm})$ initial cover, allowing early slip. Bars with a thick cover (and lower settlement cracking) will benefit more from improved consolidation than bars with a thin cover.

A similar trend is obtained for the $\# 8$ bars at ultimate, with the relative strengths increasing from 0.99 to 1.05 for $3 / 4$-in. (19-mm) cover and from 1.05 to 1.08 for 3 in. monolithic cover, as slump increases from $13 / 4$ in. $(44 \mathrm{~mm})$ to $81 / 2$ in. $(216 \mathrm{~mm})$.

The slump range $\left[2 \frac{3}{4} \mathrm{in}\right.$. $(70 \mathrm{~mm})$ to $4 \frac{1}{2} \mathrm{in}$. (115 $\mathrm{mm})]$ was not wide enough to obtain a clear trend for the \#5 bars.

Overall, high-density vibration provided an improved average bond strength, with the exception of the \#5 bars in Group 4, which were the only tests to exhibit any significant reduction in bond strength with increased consolidation.

\section{Effect of cover thickness and type}

Bars with $3 / 4-$ in. (19-mm) cover had a bond strength of only about 60 percent of bars with a 3 in. $(76 \mathrm{~mm}$ ) 


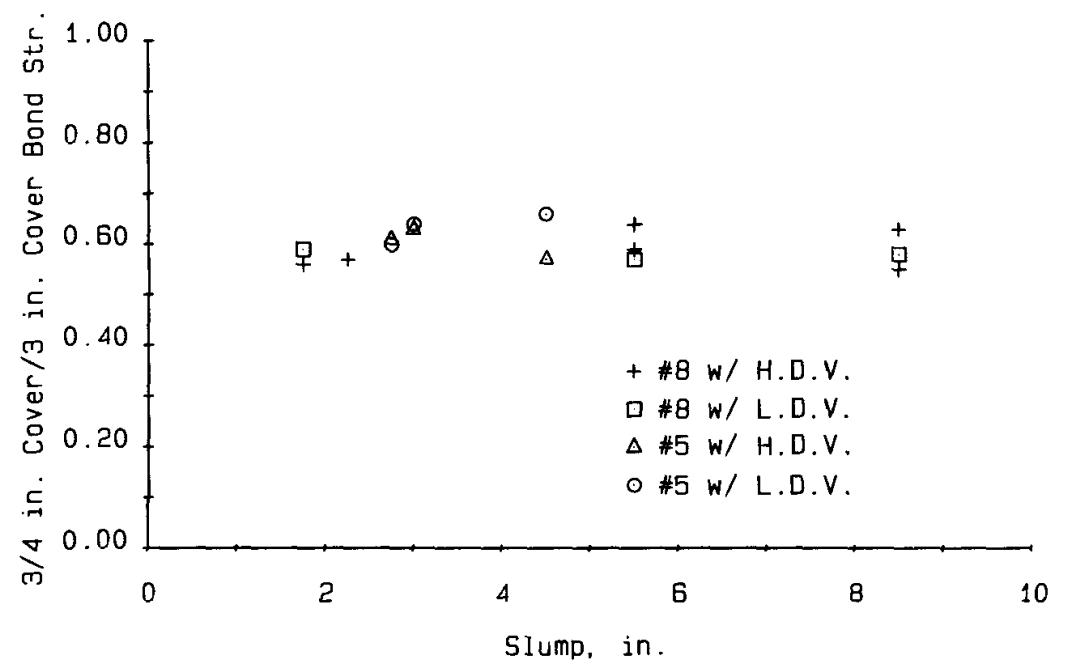

Fig. 5-Ratio of 3/4-in. cover to 3-in. cover bond strength versus slump. H.D.V. = high density vibration. L.D.V. $=$ low density vibration $(1 \mathrm{in} .=25.4 \mathrm{~mm})$

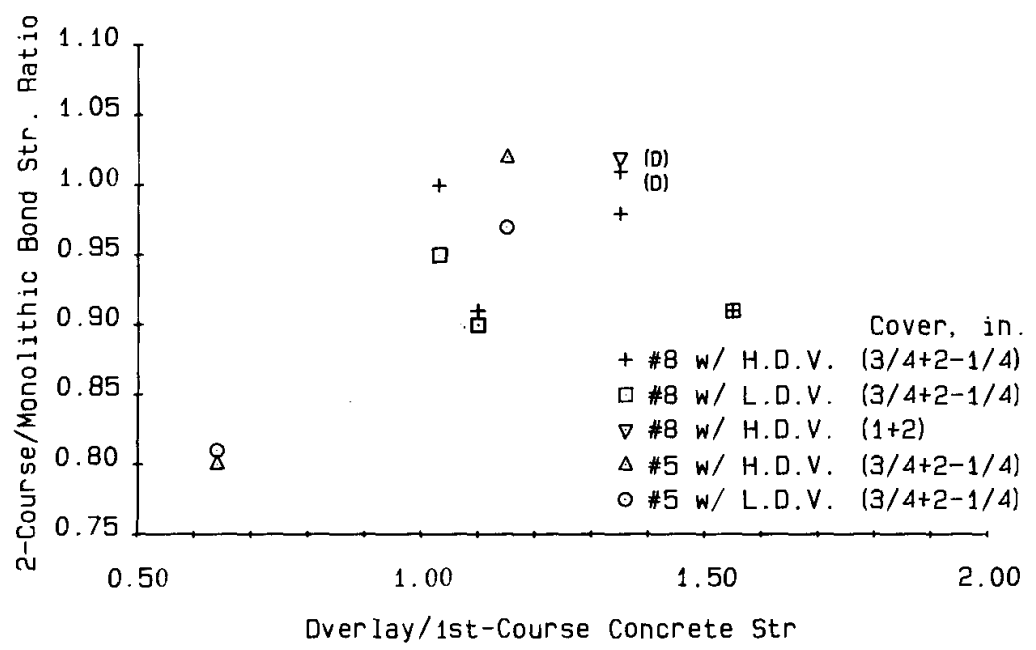

Fig. 6-Ratio of two-course to monolithic bond strength versus ratio of overlay to first-course concrete strength. H.D.V. = high density vibration. L.D.V. = low density vibration (l in. $=25.4 \mathrm{~mm})$

monolithic cover (Fig. 5). This trend appears to be independent of bar size, slump, and vibration density.

The relative bond strengths in two-course and monolithic decks are compared to the ratio of overlay to first-course concrete strength in Fig. 6. Fig. 6 shows that a low-strength overlay can reduce bond strength up to 20 percent, while high-strength overlays can, at best, achieve a bond strength equal to that obtained with a monolithic cover. The slabs with an overlay strength in excess of the first course strength attained bond strengths ranging from 90 percent to 102 percent of the bond strengths in the monolithic slabs, with most twocourse slabs showing a reduced bond strength. However, a high-strength overlay does not guarantee a high bond strength, as illustrated by the \#8 bars in Group 2, in which the bond strengths for two-course decks were only 91 percent of those with monolithic decks, even though the overlay strength was 155 percent of the first course strength.
The reduction in bond strength in the two-course decks is probably due to problems associated with low top cover in the first course, i.e., the formation of settlement cracks, coupled with the tendency of the finishing equipment to remove the coarse aggregate from the concrete above the bars. The lower coarse aggregate content above the bars will aggravate any shrinkage cracking that occurs. These longitudinal settlement and shrinkage cracks can then act as incipient bond cracks. This line of reasoning is strengthened by the observation that the bond strength reduction was the greatest for Groups 2 and 3, the groups with the highest slump first-course concrete $[81 / 2$ in. $(216 \mathrm{~mm})$ and $51 / 2$ in. $(140 \mathrm{~mm})]$; the higher the slump, the greater the settlement and shrinkage.

Should the bond between the first- and secondcourse concrete be unsatisfactory, then additional problems will arise since the effective cover will drop to $3 / 4$ in. (Fig. 5). 


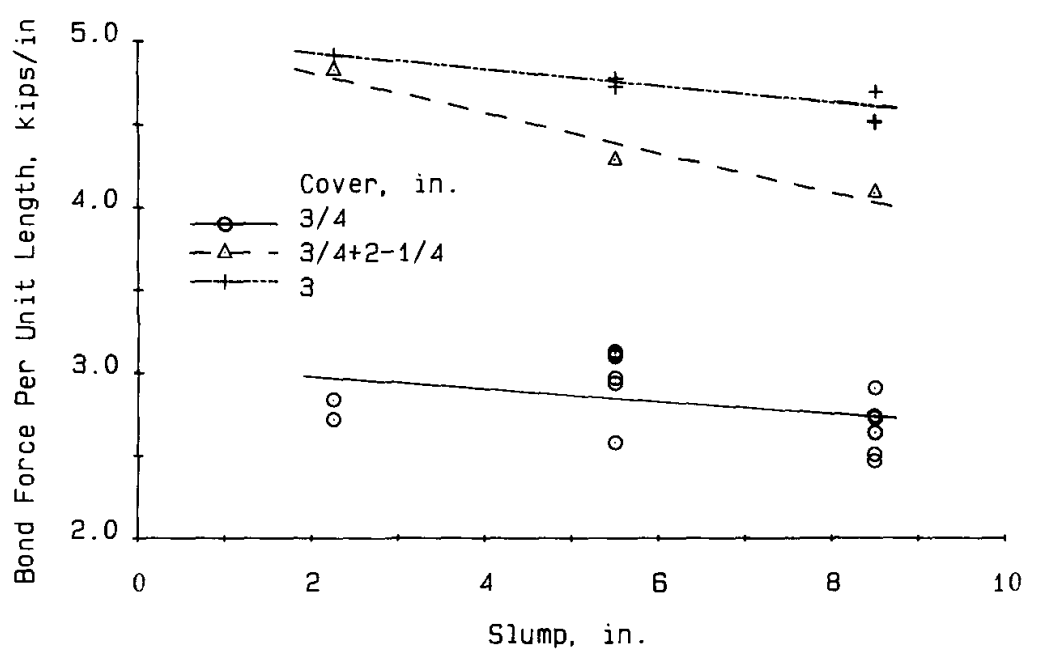

Fig. 7 - Bond forces per unit length at ultimate load for $\# 8$ bars versus slump. High-density vibration slabs from Groups 2, 3, and $8(1 \mathrm{in} .=25.4 \mathrm{~mm}, 1 \mathrm{kip} / \mathrm{in} .=1.75 \mathrm{kN} / \mathrm{m})$

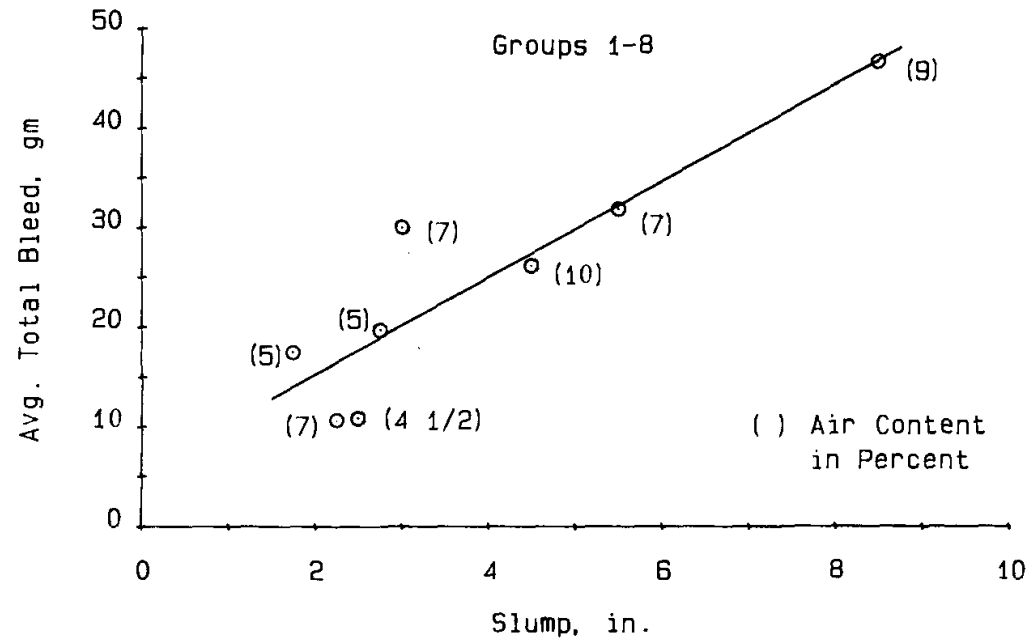

Fig. 8 - Average total bleed at $2 \mathrm{hr}$ versus concrete slump $(1 \mathrm{in} .=25.4 \mathrm{~mm})$

\section{Effect of slump and bleed}

The results generally agree with earlier work ${ }^{8,11,12}$ indicating that bond strength decreases with increasing slump (Fig. 7). However, no trend appears for \#5 bars alone, and the trends for $\# 8$ bars are not as strong as reported earlier, ${ }^{8}$ possibly because of the shallow specimens and high-density consolidation used in this study.

For the \#8 bars in Groups 2, 3, and 8 (similar firstcourse concrete strengths), average bond strengths dropped a total of 4,15 , and 6 percent, as the slump increased from $2 \frac{1}{4}$ in. $(57 \mathrm{~mm})$ to $81 / 2$ in. $(216 \mathrm{~mm})$ for the $3 / 4 \mathrm{in}$. $(19 \mathrm{~mm}), 3 \mathrm{in}$. (76 mm) two-course, and $3 \mathrm{in}$. $(76 \mathrm{~mm})$ monolithic covers, respectively.

A definite correlation between bleed and slump exists for this series of tests (Fig. 8), suggesting that the trend of decreased bond with increased slump may be due to increased bleed. There is no apparent effect of air content on bleed for air contents ranging from $4 \frac{1}{2}$ to 10 percent.

\section{Effect of specimen depth}

AASHTO ${ }^{1}$ and $\mathrm{ACl}^{2}$ require a 40 percent increase in embedment length for top bars, i.e., horizontally cast
Table 5-Comparison of bond strengths for deep slabs and shallow slabs

\begin{tabular}{|c|c|c|c|c|c|c|}
\hline \multirow[b]{2}{*}{$\begin{array}{c}\text { Group } \\
\text { No. }\end{array}$} & \multirow[b]{2}{*}{$\begin{array}{l}\text { Bar } \\
\text { size }\end{array}$} & \multirow{2}{*}{$\begin{array}{c}\text { Embedment } \\
\text { length, } \\
\text { in. }\end{array}$} & \multirow[b]{2}{*}{$\begin{array}{c}\text { Cover, } \\
\text { in. }\end{array}$} & \multicolumn{2}{|c|}{$\begin{array}{c}\text { Average } \\
\text { ultimate } \\
\text { bond force }\end{array}$} & \multirow{2}{*}{$\begin{array}{l}\text { Deep } \\
\text { shallow } \\
\text { ratio }\end{array}$} \\
\hline & & & & $\begin{array}{c}\text { Deep, } \\
\text { kips }\end{array}$ & $\begin{array}{c}\text { Shallow, } \\
\text { kips }\end{array}$ & \\
\hline 7 & $\# 8$ & 15 & $3 / 4$ & 46.8 & 37.7 & 1.24 \\
\hline 7 & $\# 8$ & 10 & 3 & 54.2 & 48.3 & 1.12 \\
\hline 8 & $\# 8$ & 10 & $3 / 4+21 / 4$ & 47.6 & 45.7 & 1.04 \\
\hline 8 & $\# 8$ & 10 & 3 & 45.9 & 47.8 & 0.96 \\
\hline
\end{tabular}

bars with more than 12 in. $(0.3 \mathrm{~m})$ of concrete below them. Following this reasoning, all of the bars in the deep slabs should have significantly lower bond strengths than the bars in the shallow slabs. This was not the case.

As shown in Table 5, the bond strengths in the deep slabs ranged from 96 to 124 percent of the bond strengths in the companion shallow slabs.

Earlier tests ${ }^{11}$ have indicated that even for low-slump, highly consolidated concrete, the depth of concrete below the top reinforcement should have at least some ef- 


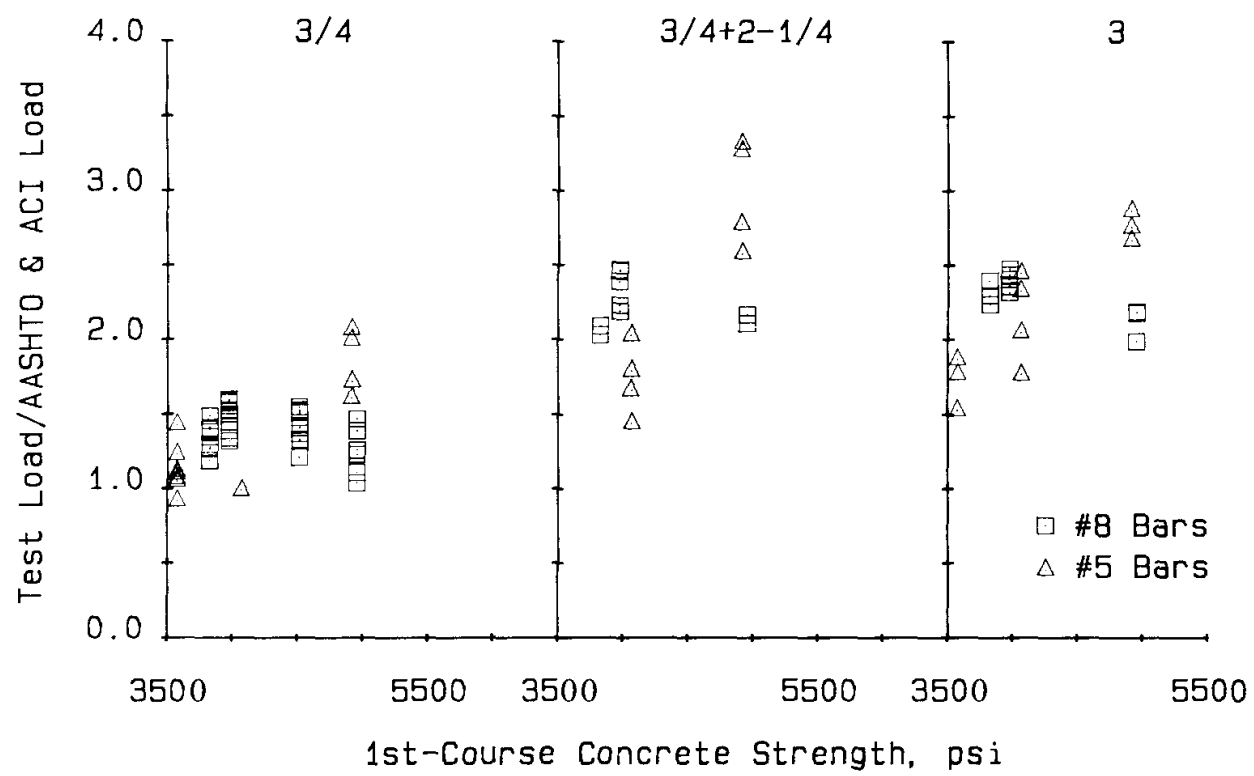

Fig. 9 - Comparison of experimental bond strengths to $A A S H T O^{1}$ and $A C T^{2}$ bond strengths $(1 \mathrm{in} .=25.4 \mathrm{~mm}, 1$ psi $=6.895 \mathrm{kPa}$ )

fect on bond. These earlier test specimens were, however, prepared so that they were the same size at the time of testing. It is possible then that the geometry of the test specimens plays a role.

The vertical cracks that were observed below the \#8 bars of ten extended to the bottom of the shallow slabs. While the vertical cracks did not extend to the bottom of the deep slabs, they did grow to more than 8 in. in length. The additional energy required to crack the deep slabs may be reflected in the high bond strength of the deep specimens. This fact does not reduce the validity of the results, since deeper structures have more concrete available to crack.

\section{Design equations}

Ideally, AASHTO and ACI bond requirements should be uniformly conservative when compared with test data. This is not the case for this study.

The expressions for development length in the AASHTO Bridge Specifications and ACI Building Code $^{2}$ can be used to obtain an ultimate bond force $T$. The following equations* are obtained for \#11 bars and smaller:

$$
\begin{aligned}
& T=1.25 \times 25 L \sqrt{f_{c}^{\prime}} \\
& T=1.25 \times 625 \pi L d_{l},
\end{aligned}
$$

For the two bars used in this study, Eq. (2) governs for \#8 bars, while Eq. (3) governs for \#5 bars.

The experimental bond strengths are compared to the predicted values [from Eq. (2) or (3)] in Fig. 9 and Table 6 . Table 6(a) includes only those bars that remained elastic, while Table 6(b) includes all valid tests. The predicted values are based on the first-course concrete strength.
The comparisons for the \#5 bars show a much greater scatter than the comparisons for the \#8 bars, because Eq. (3) does not include the concrete strength.

The AASHTO and ACI requirements are generally conservative for the \#8 bars. The requirements are less conservative for the \#5 bars.

The \#5 bars with the $3 / 4-\mathrm{in}$. (19-mm) cover are by far the least conservative, with an average strength which is 33 percent above the predicted value [Table (6a)]. The $\# 8$ bars with $3 / 4$-in. $(19-\mathrm{mm})$ cover average 38 percent above the predicted value. Coupled with the large scatter in the results, however, 20 percent of \#5 bars with $3 / 4-$ in. $(19-\mathrm{mm})$ cover can be expected to have bond strengths below the predicted value, compared to only 0.3 percent for the $\# 8$ bars. This relative lack of conservatism for the \#5 bars agrees with earlier observations made with respect to top-cast bars with low cover; ${ }^{13} 3.3$ and 0.6 percent of the $\# 5$ bars within twocourse and 3 in. (76 mm) monolithic covers, respectively, are expected to be below the predicted strengths. The corresponding values for \#8 bars are essentially zero (less than 0.01 percent).

\section{CONCLUSIONS AND RECOMMENDATIONS}

High-density consolidation and two-course construction were implemented to improve bridge deck quality

*For \#11 bars and smaller, the development length $I_{d}$ is given by "0.04 $A_{i} f$ $\sqrt{f_{c}^{\prime}}$, but not less than $0.0004 d_{b} f_{y}, "$ in which $A_{b}=$ area of individual bar, in. and $f=$ yield strength of reinforcement, psi, $^{1,2}$ For the purpose of comparison with test results, these expressions may be generalized by replacing $f$ with the actual steel stress $f_{\text {s }}$ and $l_{d}$ with the actual embedment length $L$. Substituting $T$ $=A_{b} f_{s}=\left(\pi d_{n}^{2} / 4\right) f_{s}$ and solving each expression for $T$ gives the following
acturing expressions:

$$
\begin{aligned}
& T=25 L \sqrt{f_{i}^{T}} \\
& T=625 \pi L d_{b}
\end{aligned}
$$

For reinforcement spaced laterally at least 6 in on center, as used in this research, the required development length may be multiplied by $0.8^{1,2}$ For a given embedment length $L$, this has the effect of increasing the bond force $T$ by 25 percent, giving Eq. (2) and (3). 
and to prolong deck life. These procedures have both positive and negative effects on the bond strength of top-cast bars.

\section{High-density vibration}

High-density vibration improves bond strength, increases concrete density, and reduces permeability.* Use of the procedure is recommended.

\section{Two-course construction and effect of cover on bond strength}

In most cases, two-course construction results in lower bond strengths than $3 \mathrm{in}$. (76 $\mathrm{mm})$ monolithic construction. Although the bond strengths achieved with two-course construction are generally conservative when compared with ACI and AASHTO requirements, the data are based on tests using high-strength, wellbonded overlays. Low-strength, or poorly bonded overlays will lead to much lower bond strengths.

A cover of $3 / 4$ in. $(19 \mathrm{~mm})$ provides about 60 percent of the bond strength of $3 \mathrm{in}$. ( $76 \mathrm{~mm}$ ) monolithic cover. The current work indicates that the bond strengths for a significant percentage of top-cast reinforcement with $3 / 4-$ in. $(19-\mathrm{mm})$ cover will be less than the current design requirements. ${ }^{1,2}$ This can be a problem, both during construction and in service if overlay delamination occurs.

Continued use of two-course bonded deck construction is warranted only if it can be shown that (1) highstrength, well-bonded overlays are used and (2) the procedure results in more corrosion protection than provided by $3 \mathrm{in}$. (76 mm) monolithic cover.

\section{First course cover}

Longitudinal settlement cracking, longitudinal depressions, and aggregate tears in the concrete have been noted above the top reinforcement in first-course placements. All of these can be detrimental, not only to the concrete-steel bond strength, but to the durability of the deck as well.

Longitudinal settlement cracking has been shown to be a function of top cover. ${ }^{14}$ Longitudinal depressions and aggregate tearing are brought about in the finishing operation and are probably both caused by the low cover relative to the maximum aggregate size. The commonly specified $3 / 4$ in. $(19 \mathrm{~mm})$ first course top cover is usually the same as the specified maximum aggregate size.

For two-course decks, the minimum first-course cover should be increased to $1 \mathrm{in}$. $(25 \mathrm{~mm})$, or $4 / 3$ of the maximum size aggregate, as is recommended in $\mathrm{ACI}$ $211.1 .^{15}$ This should reduce the formation of longitudinal depressions and aggregate tearing with $1 / 2$ in. (19 $\mathrm{mm}$ ) maximum size aggregate. The specified overlay thickness can then be decreased to 2 in. $(51 \mathrm{~mm})$, if required for economy.

\section{Concrete slump and slab depth}

The use of low-slump concrete [maximum $2 \frac{1}{2}$ in. (65 $\mathrm{mm}$ )] for the first course is recommended, since in-
Table 6-Comparison of experimental bond strengths to AASHTO ${ }^{1}$ and $\mathrm{ACl}^{2}$ bond strengths

(a) Bars that remained elastic

\begin{tabular}{l|c|c|c}
\hline \multirow{2}{*}{ Item } & \multicolumn{3}{|c}{ Cover } \\
\cline { 2 - 4 } & $3 / 4$ in. & $3 / 4$ in. $+21 / 4$ in. & 3 in. \\
\hline \#5 bars & 13 & 8 & 10 \\
\hline Number of bars in sample & 1.329 & 2.349 & 2.197 \\
Average $\frac{T \text { (test) }}{T[\text { [Eq. (3)] }}$ & 0.390 & 0.731 & 0.473 \\
$\begin{array}{l}\text { Sample standard deviation } \\
\text { Estimated percentage* } \\
T<T \text { [Eq. (3)] }\end{array}$ & 20 & 3.3 & 0.6 \\
\hline $\begin{array}{l}\text { \#8 bars } \\
\text { Number of bars in sample }\end{array}$ & 34 & 10 & 12 \\
Average $\frac{T \text { (test) }}{T \text { [Eq. (2)] }}$ & 1.380 & 2.224 & 2.296 \\
$\begin{array}{l}\text { Sample standard deviation } \\
\text { Estimated percentage* } \\
T<T \text { [Eq. (2)] }\end{array}$ & 0.138 & 0.155 & 0.137 \\
\hline
\end{tabular}

(b) All valid tests'

\begin{tabular}{|c|c|c|c|}
\hline \multicolumn{4}{|l|}{ \#5 bars } \\
\hline Number of bars in sample & 16 & 8 & 12 \\
\hline Average $\frac{T(\text { test })}{T[\mathrm{Eq} \cdot(3)]}$ & 1.288 & 2.349 & 2.354 \\
\hline & 0.362 & 0.731 & 0.654 \\
\hline$T<T$ [Eq. (3)] & 21 & 3.3 & 2 \\
\hline \multicolumn{4}{|l|}{$\# 8$ bars } \\
\hline Number of bars in sample & 34 & 12 & 16 \\
\hline Average $\frac{T \text { (test) }}{T[\mathrm{Eq} \cdot(2)]}$ & 1.380 & 2.283 & 2.308 \\
\hline $\begin{array}{l}\text { Sample standard deviation } \\
\text { Estimated percentage* }\end{array}$ & 0.138 & 0.141 & 0.134 \\
\hline$T<T$ [Eq. (2)] & 0.3 & 0 & 0 \\
\hline
\end{tabular}

${ }^{*}$ Assuming normal distribution.

Includes bars that yielded prior to pullout.

Note: $1 \mathrm{in} .=25.4 \mathrm{~mm}$

creased slump is detrimental to bond strength. Although the data are limited, deep slabs made with stiff, well-consolidated concrete can provide the same bond strengths as shallow slabs.

\section{ACKNOWLEDGMENTS}

This research was supported by the state of Kansas Department of Transportation under a contract with the University of Kansas Center for Research, Inc. Vibrating and finishing equipment was supplied by Allen Engineering Corp. Reinforcing steel was provided by Armco, Inc., and Sheffield Steel Corp. The high-range water reducer was supplied by Gifford-Hill and Co., Inc. The water blaster was supplied by District I of the Kansas Department of Transportation. Additional support was provided by the University of Kansas Department of Civil Engineering. Special thanks are due Carl F. Crumpton and John B. Wojakowski of the Kansas Department of Transportation Bureau of Materials and Research for their detailed comments on the original work. ${ }^{+}$

\section{REFERENCES}

1. Standard Specifications for Highway Bridges, 12th Edition, American Association of State Highway and Transportation Officials, Washington, D.C., 1977, 496 pp.

\footnotetext{
*Burkovatz, John E., unpublished data from a Kansas Department of Transportation study.
} 
2. ACI Committee 318, "Building Code Requirements for Reinforced Concrete (ACI 318-77)," American Concrete Institute, Detroit, 1977, $102 \mathrm{pp}$.

3. Donahey, Rex C., and Darwin, David, "Effects of Construction Procedures on Bond in Bridge Decks," SM Report No. 7, University of Kansas Center for Research, Lawrence, Jan. 1983, $125 \mathrm{pp}$.

4. Donahey, Rex C., and Darwin, David, "Effects of Innovative Construction Procedures on Concrete Bridge Decks, Final Report: Part 1, Effects of Construction Procedures on Bond in Bridge Decks," SL Report No. 83-1, University of Kansas Center for Research, Lawrence, June 1983, 28 pp.

5. "Standard Test Method for Bleeding of Concrete," (ASTM C 232-71) (Reapproved 1977), 1980 Annual Book of ASTM Standards, Part 14, ASTM, Philadelphia, pp. 167-172.

6. "Standard Test Method for Specific Gravity, Absorption, and Voids in Hardened Concrete," (ASTM C 642-75), 1980 Annual Book of ASTM Standards, Part 14, ASTM, Philadelphia, pp. 388-390.

7. Ferguson, Phil M., and Thompson, J. Neils, "Development Length of High Strength Reinforcing Bars in Bond," ACI Journal, Proceedings V. 59, No. 7, July 1962, pp. 887-922.

8. Luke, J. J.; Hamad, B. S.; Jirsa, J. O.; and Breen, J. E., "The Influence of Casting Position on Development and Splice Length of Reinforcing Bars,' Research Report No. 242-1, Center for Transportation Research, Bureau of Engineering Research, The University of Texas at Austin, June 1981, 153 pp.
9. Untrauer, Raymond E., and Warren, George E., "Stress Development of Tension Steel in Beams," ACI Journal, Proceedings V. 74, No. 8, Aug. 1977 , pp. 368-372.

10. Jimenez-Perez, Rafael; Gergely, Peter; and White, Richard N., "Shear Transfer Across Cracks in Reinforced Concrete," Report No. 78-4, Department of Structural Engineering, Cornell University, Ithaca, Aug. 1978, 357 pp.

11. Menzel, Carl A., "Effect of Settlement of Concrete on Results of Pullout Tests," Research Department Bulletin No. 41, Portland Cement Association, Skokie, Nov. 1952, 49 pp.

12. Zekany, A. J.; Neumann, S.; Jirsa, J. O.; and Breen, J. E., "The Influence of Shear on Lapped Splices in Reinforced Concrete," Research Report No. 242-2, Center for Transportation Research, Bureau of Engineering Research, The University of Texas at Austin, July 1981, 88 pp.

13. Untrauer, R. E., Discussion of "Development Length for Large High Strength Reinforcing Bars" by Phil M. Ferguson and J. Neils Thompson, ACl Journal, Proceedings V. 62, No. 9, Sept. 1965, pp. 1153-1154.

14. Dakhil, Fahd H.; Cady, Philip D.; and Carrier, Roger E., "Cracking of Fresh Concrete as Related to Reinforcement," $\mathrm{ACl}$ Journal, Proceedings V. 72, No. 8, Aug. 1975, pp. 421-428.

15. ACI Committee 211, "Standard Practice for Selecting Proportions for Normal, Heavyweight and Mass Concrete (ACI 211.1-81)," American Concrete Institute, Detroit, 1981, 32 pp. 